\section{The magnitude of perinatal mortality rate and associated risk factors among deliveries at Dilla University Referral Hospital, Southern Ethiopia: A case-control study}

\author{
Kefale Lelamo Legu, Alemu Tamiso \\ Debiso, Kaleb Mayisso Rodamo
}

Hawassa University College of Medicine and Health Sciences, Hawassa

\begin{abstract}
The perinatal mortality rate is the sum of stillbirths and early neonatal deaths divided by the number of pregnancies of seven or more months' duration. In Ethiopia, the death rate was 33 deaths/1000 total births in 2016. We aimed to identify the perinatal mortality rate and associated risk factors among deliveries in Dilla University Referral Hospital; January, 2016 - December, 2018. A hospital based retrospective case-control study was conducted using subgroup binary logistic regression analysis including 138 cases and 296 control group. The proportion of hospital perinatal deaths was $30 \%$ with $90 \%$ of the deaths were occurred as a result of stillbirths and antepartum hemorrhage. Adjusted odds ratios revealed that history of still birth, very low birth weight, short interval and nonuse of partograph found to be independent predictors of both stillbirths and early neonatal deaths besides to pregnancy induced hypertension and antepartum hemorrhage. The risk of perinatal mortality may be increased by not treating chronic illnesses, obstetrics complications and risk factors causing low birth weight as well as short birth intervals and not using partograph during labour.
\end{abstract}

\section{Introduction}

The Perinatal Mortality Rate is defined as the sum of the number of perinatal deaths (stillbirths and early neonatal deaths/ENND) divided by the number of pregnancies of seven or more months' duration (all live births plus stillbirths). PMR is determined by the distinct features of antepartum, intra partum, and neonatal periods (a death in the first seven days of a child born alive). Stillbirth is intrauterine death occurs either before onset of labour (antepartum death) or during labour (intra partum death) and classified as a fetal deaths $\geq 28$ weeks gestation, weight of $\geq 1000$ grams or a body length of $\geq 35 \mathrm{~cm} .{ }^{1-3}$ Annually 2.5 million neonatal deaths and 2.6 million stillbirths occur globally ${ }^{4,5}$ of which 1.3 million are intra partum stillbirths; and $41 \%$ of new-born deaths. $70 \%$ of stillbirths could be averted with an integrated cost effective antenatal and essential obstetric care. ${ }^{1,3,5}$

Perinatal death assumed to be an important public health problem and key indicator of poor health status in low income settings where the death is maintained in very high rates. Birth asphyxia, birth injury, preterm low birth weight, birth interval of $<2$ years, young maternal age at birth, low level education, poor maternal nutrition, absence of Antenatal Care (ANC) and complications during labour were primary causes initiating the cascade of perinatal death. ${ }^{6,8}$ In Ethiopia, the PMR was 33 deaths/1000 pregnancies of seven or more months' duration (30 still births and 29 neonatal deaths), despite neonatal deaths shown a reduction of $17 \%$ over the past 5 years with significant disparities per 1,000 live births of 43 PMR in rural and 41 PMR in urban settings. ${ }^{9,10}$ In the southern region, threefold of the national figure was reported, with Pregnancy Induced Hypertension (PIH) being a single most important risk factor and obstructed labor accounted for $26 \%$ of hospital deaths with $50 \%$ of still births and 2-5 folds of ENND. ${ }^{10,11}$

To the authors' knowledge, data on the rate of perinatal deaths were very old and were obtained from urban residents rather than from remote population where the rate and the risk factors of perinatal deaths were poorly documented. ${ }^{12}$ Hence, the study aimed to assess the rate and risk factors associated with perinatal mortality so as to fill the existing gap of data and knowledge using local epidemiological study findings of these kinds and to establish a foundation of knowledge and understanding.

\section{Materials and Methods}

\section{Study site}

A hospital based case-control study was conducted from April 1 1st-30 $0^{\text {th }}, 2019$ at Dilla University Referral Hospital (DURH); a referral hospital for Gedeo zone where the total population is estimated to be 1 million, as extrapolated from the 2007 national census. The hospital was selected based on availability of both delivery and neonatal intensive care units.

\section{Study population}

All deliveries conducted from January
Correspondence: Kaleb Mayisso Rodamo, Hawassa University College of Medicine and Health Sciences, P.O Box 1560, Hawassa. Tel.: +251.919532392 Fax: +251.0462208755 E-mail: kalebmayisso@gmail.com

Key words: Perinatal death; case-control study; Ethiopia.

Acknowledgments: We are very grateful to the college of medicine and health sciences, Hawassa University, for funding the research.

Contributions: KLL contributed to conduct interviews, to the conception or design of the work; or the acquisition, analysis, or interpretation of data for the work, KMR contributed to drafting the work or revising it critically for important intellectual content; writing the manuscript, final approval of the version to be published and ATD contributed as content expert and to manu-script editing, to ensure the accuracy or integrity of any part of the work are appropriately investi-gated and resolved. All authors read and approved the final manuscript.

Conflict of interests: The authors have no conflicts of interest to declare.

Further information: This work was supported by a budget for a student research of college of medicine and health sciences, Hawassa University.

Availability of data: All data generated or analyzed during this study are included in this the arti-cle.

Ethics approval and consent to participate: Ethical approval and clearance were obtained from Institutional Review Board of Hawassa University, College of Medicine and Health Sciences. Since this analysis used entirely registered data, there was no need of obtaining informed written consent. Therefore, verbal informed consent was obtained from the mothers using telephone call to prove that discharged neonates were alive up to 7 completed days. The consent was incorporated with consideration of the right of volunteer participation and consent based subject's best interest to participate in the research, both initially and during the course of the research based on Helsinki's declaration. Moreover, the consent was approved by the Institutional Review Board of Hawassa University, College of Medicine and Health Sciences.

Received for publication: 7 August 2021.

Revision received: 23 November 2021.

Accepted for publication: 29 November 2021.

This work is licensed under a Creative Commons Attribution 4.0 License (by-nc 4.0).

${ }^{\circ}$ Copyright: the Author(s), 2021

Licensee PAGEPress, Italy

Healthcare in Low-resource Settings 2021; 9:9960 doi:10.4081/hls.2021.9960 
$1^{\text {st }} 2016$ - December $30^{\text {th }} 2018$ were used as a source population. Fetal deaths at $28 \mathrm{com}$ plete weeks of gestation and live newborns died in the first week of life were used as cases, while control group were newborn delivered alive who did not die before the age of first seven days of life. All medical charts with incomplete records and referred from others institution because of associated complications were excluded.

The minimum required sample size was calculated using single proportion formula in a population as described in open EPIinfo 2002, version 3, open source calculator. ${ }^{13}$ We assumed $54.3 \%$ frequency of the coexisting newborns low birth weight, one of the factors strongly associated with perinatal mortality from the study conducted in Addis Ababa public hospitals, with Adjusted Odds Ratio (AOR) of 16.45; 95\% CI (9.57-28.26). ${ }^{12}$ The value of $95 \%$ confidence interval $(\mathrm{CI})$, power of $80 \%$ (1B) and 5\% margin of error; and a nonresponse rate of $15 \%$ and a control to case ratio of 2:1, an estimated sample size of 438 (138 cases and 300 control group) sufficient to determine associated factors.

From 2016-2018 delivery reports, cases were traced systematically using delivery, operation and neonatology log books of the hospital. For each case, 2 other babies delivered in the same day as the cases, one before and one after each case, were selected and prepared based on inclusion criteria. For subgroup analysis, the matching of cases in the control group was changed from 1:2 in the total cases to control to 1:2.4 in stillbirth to control and to 1:20 in ENND to control group.

\section{Variables}

Outcome variables: this study selected the perinatal death as an outcome variable which is categorized as "Yes" for who experienced still birth or ENND and "No" for did not experienced still birth or ENND.

The independent variables selected for the purpose of analyses were: Socio-demographic variables: Age of the mother: the mother's age at child birth and categorized as: i) less than 18 years, 18-34 years, and 35-49 years; ii) family size: based on the number of family members and dichotomized as small, medium and large family: iii) maternal education: categorized as: no education, elementary education, and higher education; iv) marital status of the mother, dichotomized as currently married and not married; v) house hold wealth: was dichotomized as low, medium and high wealth scores; vi) place of residence: was dichotomized as rural or urban residences; vii) maternal occupation: was categorized as: house wife, employed, daily laborer and farmer; and viii) the household's religion was dichotomized as: protestant, orthodox or Muslim.

Maternal obstetric conditions: Obstetrics complications associated with pregnancy, labor and child birth were: i) $\mathrm{APH}$, multiple pregnancy, premature rupture of membrane, prolonged and obstructed labor, cord accidents and PIH; ii) parity of the mother: categorized as primiparous, multipara and grand multipara; iii) pregnancy intention: based on women's self-reports of their desire to become pregnant right before the conception occurred was categorized as: intended, mistimed or unwanted.

Previous history of perinatal death: was categorized as: i) still birth, early neonatal death and no history of perinatal death; ii) history of abortion, both spontaneous and medically induced termination of pregnancy before the $28^{\text {th }}$ week of gestation and dichotomized as yes (ever experienced)/no (never experienced); iii) fetal presentations: was trichotomized as vertex, breech and transverse; iv) mode of deliver: was trichotomized as spontaneous vaginal delivery, caesarean section and instrumental delivery; and v) antenatal follow up and use of partograph were dichotomized as yes/no.

Coexisting medical conditions of the mothers: i) history of chronic illnesses: diabetes mellitus, renal and cardiac diseases; ii) tuberculosis, HIV/AIDS and malaria were considered as common infectious diseases; and iii) maternal anemia: we trichotomized based on hemoglobin level of first, second and third trimester of pregnancy as severe anemia, moderate anemia, mild anemia and no anemia.

Fetal and newborn conditions: i) gestational age of the new born: was calculated from the last menstrual period and categorized as: preterm, term and post term neonates; ii) duration of the labor: was categorized based on the length for the stage of labor as: 12 hour-19 hour-normal first stage, $>20$ hour -prolonged first stage- $20 \mathrm{~min}-2$ hours-second stage labor, and third stage- 5 hour-30 hour; iii) weight at birth: was categorized as smaller than average, average and larger than average; iv) newborn Apgar score: was generally done at $1^{\text {st }}$ and $5^{\text {th }}$ minutes after birth and categorized based on the scores as: - normal, fairly low and critically low; v) birth interval: was dichotomized as preceding interval $<2$ years and preceding interval 2 or more years; vi) birth order, was trichotomized as: first/second-born, thirdborn, and fourth/higher order born; vii) neonatal sepsis: dichotomized based on the time of presentation after birth as earlyonset sepsis and late-onset sepsis; viii) birth asphyxia: dichotomized into two grades of severity, pale asphyxia and acute asphyxia; and ix) neonatal anemia: trichotomized based on hemoglobin level as severe anemia, moderate anemia, and mild anemia.

\section{Data collection}

Two midwives who were trained for 5 days collected the data so that mothers would be comfortable to discuss reproductive health matters that they may not be comfortable to discuss with men. A phone call was made to prove that the discharged neonates were alive up to 7 completed days after verbal informed consent was obtained. For a neonate discharged alive and died before seven completed days, the next alive neonate was taken as a control group. The mother was taken as a non-respondent if she didn't respond to a phone call or if she was not available. Social, demographic and economic data of the households were taken from admission register and medical log books. All data of fetal and neonatal conditions such as birth weight, gestational age of the neonate etc. and coexisting medical and obstetrics conditions were obtained from antenatal records, maternal admission register and log books, delivery and labor summary of the mother, ultrasonography records and medical records of neonates.

\section{Data analysis}

The data were coded, checked and

Table 1. Distribution of perinatal deaths (cases) and control group by year of study, Dilla Univer-sity Referral Hospital, Ethiopia, 2016-2018.

\begin{tabular}{lcccc} 
Year & 2016 & 2017 & 2018 & Total \\
Total babies born & 398 & 538 & 688 & 1624 \\
Cases & 36 & 43 & 59 & 138 \\
\hline Control group & 74 & 98 & 128 & 300 \\
PMR & 90 & 86 & 86 & 85 \\
\hline Stillbirths & 35 & 38 & 50 & 123 \\
ENND & 4 & 5 & 6 & 15 \\
\hline SB to ENND ratio & $9: 1$ & $8: 1$ & $8: 1$ & $8: 1$ \\
\hline
\end{tabular}

$\mathrm{PMR}=$ perinatal mortality rate, $\mathrm{ENND}=$ early neonatal death, SB to ENND ratio= still birth to early neonatal death ratio. 
entered using Epi-Info version 7 and exported into SPSS version 22.0 computer software programs for analysis. Still-birth, perinatal and ENND death rates were calculated using descriptive statistics and cross tabulation. Bivariate logistic regression analysis was conducted to measure the association between the dependent and independent variables and those variables associated with significance level of $\mathrm{p}$ value $<0.05$ were transferred into multivariate logistic regression model to identify the important determinants by controlling possible confounders, and the strength of association was measured using OR with $95 \%$ CI of a $p$ value $<0.01$. A total of 10 dichotomous household asset variables were involved to generate wealth index using principal component analysis. According to the index, households were divided in to quintiles ranging from the poorest $50 \%$ to the richest $2 \%$.

\section{Results}

In a period of three years, a total of 1624 deliveries of all types were registered with a perinatal deaths of 138 (123 stillbirths and 15 ENND); and overall PMR of 85 per 1,000 total pregnancies of 7 or more months' duration (Table 1). Still-births accounted for more than two-third (67\%) of the mothers admitted to the hospital due to fetal deaths. Among the hospital admissions due to fetal deaths, thirty mothers were admitted with positive fetal heartbeats and reported as hospital stillbirths later on. The proportion of hospital deaths, the death of fetus recorded as "alive" on admission and later on reported as stillbirths plus ENND new borne babies died in the hospital before seven days of life were a quarter $(33 \%)$ of a total perinatal deaths. Antepartum Hemorrhage (APH) contributed for about $44 \%$ of overall perinatal deaths, $40 \%$ of the hospital perinatal deaths and $53 \%$ of ENND (Table 2). The majority (91\%) of the moth- ers in the cases and $270(90 \%)$ in the control groups were married and $(96 \%)$ of the mothers in the cases and $57 \%$ in the control groups were rural dwellers with the literacy rate of $50 \%$ in both the groups. Because of only 10 and $11 \%$ of the mothers in cases and in control group respectively were employed, $62 \%$ of them in the cases and $56 \%$ in the control group lied with in low wealth quintiles (Table 3 ).

The study demonstrated $22 \%$ of the mothers in the control group and $20 \%$ in the cases were primiparous and least $(9 \%)$ of the mothers in cases had planned for the current pregnancy. More than three-fourth of the mothers in the control group had ANC follow up and two-third used partograph during the labor. Nearest to threefourth of the mothers in the cases had not ANC follow up and more than three-fourth were not used partograph during the labor. The majority $(96 \%)$ of the mothers in the control group and in the cases (82\%) experienced vertex presentation and more than

Table 2. The proportion of perinatal deaths before and after arriving at the hospital by type of ob-stetric complications, Dilla University Referral Hospital, Ethiopia, 2016-2018.

\begin{tabular}{|c|c|c|c|c|c|c|c|c|}
\hline \multirow{2}{*}{ Obstetric complication } & \multicolumn{2}{|c|}{ Total cases } & \multicolumn{2}{|c|}{ Stillbirths before arrival } & \multicolumn{4}{|c|}{ Hospital deaths (N) } \\
\hline & Number & $\%$ & Number & $\%$ & $\begin{array}{r}\text { Still } \\
\text { Number }\end{array}$ & $\%$ & Number & $\%$ \\
\hline PIH & 61 & 44 & 41 & 44 & 12 & 40 & 8 & 53 \\
\hline $\mathrm{APH}$ & 61 & 44 & 39 & 42 & 16 & 53 & 6 & 40 \\
\hline Obstructed labor & 6 & 4 & 4 & 4 & 2 & 7 & 0 & 0 \\
\hline PROM & 5 & 4 & 5 & 5 & 0 & 0 & 0 & 0 \\
\hline Mal-presentation & 2 & 1 & 1 & 1 & 0 & 0 & 1 & 7 \\
\hline Cord accident & 3 & 2 & 3 & 3 & 0 & 0 & 0 & 0 \\
\hline$\underline{\text { Total }}$ & 138 & & 93 & & 30 & & 15 & \\
\hline
\end{tabular}

ENND=early neonatal death, $\mathrm{APH}=$ antepartum hemorrhage, $\mathrm{PIH}=$ pregnancy induced hyperten-sion, $\mathrm{PROM}=$ premature rapture of membrane.

Table 3. Socio economic and demographic variables of the mothers, Dilla University Referral Hospital, Ethiopia, 2016- 2018 (n=438).

\begin{tabular}{|c|c|c|c|c|c|}
\hline & & Cases & & Control grou & 300) \\
\hline & & Number & Percent & Number & Percent \\
\hline Marital status & Currently married & 125 & 91 & 270 & 90 \\
\hline & Currently single & 13 & 9 & 30 & 10 \\
\hline Occupation & House wife & 96 & 69 & 240 & 80 \\
\hline & Employed & 12 & 9 & 34 & 11 \\
\hline & Daily labor & 18 & 13 & 10 & 3 \\
\hline & Farmer & 12 & 9 & 12 & 4 \\
\hline & House wife & 96 & 69 & 240 & 80 \\
\hline Residences & Urban residents & 15 & 11 & 128 & 43 \\
\hline & Rural residents & 133 & 96 & 170 & 57 \\
\hline Maternal education & No education & 72 & 52 & 157 & 52 \\
\hline & Primary education (1-6) & 53 & 38 & 106 & 35 \\
\hline & Secondary education $(7+)$ & 13 & 10 & 37 & 12 \\
\hline Wealth quintiles & Low wealth score & 85 & 62 & 168 & 56 \\
\hline & Medium wealth score & 35 & 25 & 90 & 30 \\
\hline & High wealth score & 18 & 13 & 42 & 14 \\
\hline Family size & Small family (2-4) & 8 & 6 & 15 & 5 \\
\hline & Medium family $(5-10)$ & 50 & 36 & 185 & 62 \\
\hline & Large family (>10 m) & 80 & 58 & 100 & 33 \\
\hline
\end{tabular}


three fourth in the cases delivered by Spontaneous Vaginal Deliver (SVD) and the remaining delivered with caesarean section and instrumental deliveries. $90 \%$ of the mothers in the control group and $84 \%$ in the cases had no previous history of abortion and $86 \%$ of them in cases and $98 \%$ in control group had no previous history of perinatal deaths (Table 4).

The mean age in the case of perinatal deaths was $26.5 \pm 6.3$ and $27 \pm 5.8$ years in the control group. Among 132 (96\%) of the cases of perinatal deaths who experienced single gestation, $76(55 \%)$ had given birth to their first babies. Close to $88 \%$ of the cases of perinatal deaths had smaller than average weight at birth and only two new borne were weighing 2500-3999 grams. More than two-third of the new borne in the control group had average birth weight and $10 \%$ weighted more than 4000 grams. More than three-fourth of the cases in perinatal deaths had delivered at an interval of less than two years of preceding birth while the majority (93\%) in the control group had delivered at an interval of more than two years of preceding birth. Gestational age at delivery in two-third of the cases was term and $7 \%$ were post-term; and three-fourth of the cases of the perinatal death had prolonged labor. Gestational age at deliver in the majority $(92 \%)$ of the control group were at term and $3 \%$ were post term; and only $3 \%$ of the control group had 25-48 hour's median duration of labor. The majority $(92 \%)$ of the cases in neonatal death had critically low Apgar score during $1^{\text {st }}$ minutes and 3\% had seven and above Apgar score during $1^{\text {st. }}$ minutes. Similarly, $94 \%$ of the cases in neonatal deaths had critically low Apgar scores during $5^{\text {th. }}$ minutes. Threefourth of the cases in neonatal deaths had a hemoglobin level of $<70 \mathrm{~g} / \mathrm{L}$ whereas similar proportion of the control had a hemoglobin level of $110-90 \mathrm{~g} / \mathrm{L}$. Seventy four $(54 \%)$ of the cases in neonatal deaths had developed early onset neonatal sepsis and 8\% had developed neither types of neonatal sepsis. Three-fourth of the cases in neonatal deaths had developed severe asphyxia and the least $(8 \%)$ had neither types of neonatal asphyxia (Table 5).

The majority $88 \%$ of the mothers of the cases of perinatal deaths had previous history of chronic medical illnesses and $12 \%$ had no previous history of the illnesses. Majority of the mothers' were negative of HIV/AIDS infection in the cases and in the control group whereas neither of the mothers in both the cases and in the control group was positive of Hepatitis B virus infection. The least $(16 \%)$ of the mothers in the cases were reactive for Venereal Disease Research Laboratory (VDRL). Nearest to two-third of the mothers in the cases had not ever infected either with malaria or tuberculosis (Table 6).

The association of obstetric conditions and perinatal deaths as cases was tested in binary and multiple logistic regression analysis. Those obstetrics conditions shown significant association in crude analysis with a p-value of $<0.05$ had been transferred to multivariate logistic regression model for adjusted analysis to rule out possible confounding factors. Adjusted analysis showed that ENND was highest among mothers who had short birth interval $(<2$ years between births) $(\mathrm{AOR}=0.37,95 \% \mathrm{CI}$ : $0.17-0.82$ ), a $p$ value $<0.01$, than mothers who had birth interval of $>2$ years. Very low birth weight newborns had 1.9 times increased risk of ENND (AOR=0.19, 95\% CI: $0.06-0.52)$, a $p$ value $<0.01$, than normal weight newborns. Babies born to women with history of chronic illness showed 0.2 times higher odds of still births $(\mathrm{AOR}=0.13$, 95\% CI: $0.05-0.33$ ), a $p$ value $<0.01$ than babies born to women with no history of chronic illness. Labor not followed up with pantographs had 0.1 times higher odds of still births $(\mathrm{AOR}=0.10,95 \%$ CI: $0.03-$ 0.26 ), a $\mathrm{p}$ value $<0.00$, as compared to labor followed up with pantographs. In subgroup analysis, APH $(\mathrm{AOR}=0.03,95 \% \mathrm{CI}$ : 0.01 $0.02)$, a $p$ value $<0.01$ and $\mathrm{PIH}(\mathrm{AOR}=0.02$, 95\% CI: $0.01-0.03)$, a $\mathrm{p}$ value $<0.00$ had higher risk of still births more than other obstetrics complications including obstructed labour, cord accident and premature rapture of membrane (Table 7).

Table 4. Obstetrics characterstics of mothers, Dilla University Referral Hospital, Ethiopia, 2016- 2018.

\begin{tabular}{|c|c|c|c|c|c|}
\hline \multirow[t]{2}{*}{ Obstetric variables } & & \multicolumn{2}{|c|}{ Cases (138) } & \multicolumn{2}{|c|}{ Control group (300) } \\
\hline & & No. & $\%$ & No. & $\%$ \\
\hline \multirow[t]{3}{*}{ Age } & $<18$ years & 16 & 12 & 23 & 8 \\
\hline & 18-34 years & 98 & 71 & 232 & 77 \\
\hline & $35-49$ years & 24 & 17 & 45 & 15 \\
\hline Pregnancy & $\begin{array}{l}\text { Intended } \\
\text { Mistimed } \\
\text { Unwanted }\end{array}$ & $\begin{array}{l}12 \\
89 \\
37\end{array}$ & $\begin{array}{c}9 \\
64 \\
27 \\
\end{array}$ & $\begin{array}{c}260 \\
30 \\
10 \\
\end{array}$ & $\begin{array}{c}87 \\
10 \\
3 \\
\end{array}$ \\
\hline ANC follow up & $\begin{array}{l}\text { Yes } \\
\text { No }\end{array}$ & $\begin{array}{c}37 \\
101\end{array}$ & $\begin{array}{l}27 \\
73\end{array}$ & $\begin{array}{c}231 \\
69\end{array}$ & $\begin{array}{l}77 \\
23\end{array}$ \\
\hline Partograph used & $\begin{array}{l}\text { Yes } \\
\text { No }\end{array}$ & $\begin{array}{c}27 \\
111\end{array}$ & $\begin{array}{l}20 \\
80\end{array}$ & $\begin{array}{l}194 \\
106\end{array}$ & $\begin{array}{l}65 \\
35 \\
\end{array}$ \\
\hline Parity & $\begin{array}{l}\text { I } \\
\text { II-IV } \\
\mathrm{V}_{+}\end{array}$ & $\begin{array}{l}100 \\
27 \\
11\end{array}$ & $\begin{array}{c}72 \\
20 \\
8\end{array}$ & $\begin{array}{c}213 \\
67 \\
20\end{array}$ & $\begin{array}{c}71 \\
22 \\
7\end{array}$ \\
\hline Fetal presentation & $\begin{array}{l}\text { Vertex } \\
\text { Transvers } \\
\text { Breech }\end{array}$ & $\begin{array}{c}113 \\
13 \\
12\end{array}$ & $\begin{array}{c}82 \\
9 \\
9\end{array}$ & $\begin{array}{c}287 \\
5 \\
8 \\
\end{array}$ & $\begin{array}{c}96 \\
1 \\
3 \\
\end{array}$ \\
\hline Mode of delivery & $\begin{array}{l}\text { SVD } \\
\mathrm{C} / \mathrm{S} \\
\text { Instrumental }\end{array}$ & $\begin{array}{l}107 \\
21 \\
10\end{array}$ & $\begin{array}{c}78 \\
15 \\
7\end{array}$ & $\begin{array}{c}258 \\
36 \\
6\end{array}$ & $\begin{array}{l}86 \\
12 \\
2\end{array}$ \\
\hline History of abortion & $\begin{array}{l}\text { Yes } \\
\text { No }\end{array}$ & $\begin{array}{c}22 \\
116\end{array}$ & $\begin{array}{l}16 \\
84\end{array}$ & $\begin{array}{c}31 \\
269\end{array}$ & $\begin{array}{l}10 \\
90\end{array}$ \\
\hline History of perinatal deaths & $\begin{array}{l}\text { Still births } \\
\text { ENND } \\
\text { No history }\end{array}$ & $\begin{array}{c}4 \\
15 \\
119 \\
\end{array}$ & $\begin{array}{c}3 \\
11 \\
86 \\
\end{array}$ & $\begin{array}{c}6 \\
0 \\
294 \\
\end{array}$ & $\begin{array}{c}2 \\
0 \\
98 \\
\end{array}$ \\
\hline
\end{tabular}


Table 5. Fetal and Newborn characteristics, Dilla University Referral Hospital, Ethiopia, 2016-2018.

\begin{tabular}{|c|c|c|c|c|c|}
\hline \multirow[t]{2}{*}{ Variables } & & \multicolumn{2}{|c|}{ Cases (138) } & \multicolumn{2}{|c|}{ Control group (300) } \\
\hline & & No. & $\%$ & No. & $\%$ \\
\hline Number of gestation & $\begin{array}{l}\text { Single } \\
\text { Multiple }\end{array}$ & $\begin{array}{c}132 \\
6\end{array}$ & $\begin{array}{c}96 \\
4\end{array}$ & $\begin{array}{c}293 \\
7\end{array}$ & $\begin{array}{c}98 \\
2\end{array}$ \\
\hline Birth weight in grams & $\begin{array}{l}1000-1499 \\
1500-2499 \\
2500-3999 \\
\geq 4000\end{array}$ & $\begin{array}{c}128 \\
8 \\
2 \\
0\end{array}$ & $\begin{array}{c}92.7 \\
5.7 \\
1.4 \\
0\end{array}$ & $\begin{array}{c}14 \\
56 \\
200 \\
30\end{array}$ & $\begin{array}{c}4 \\
19 \\
67 \\
10\end{array}$ \\
\hline Birth interval & $\begin{array}{l}<2 \text { years } \\
>/=2 \text { years }\end{array}$ & $\begin{array}{c}128 \\
10\end{array}$ & $\begin{array}{c}92.7 \\
7.2\end{array}$ & $\begin{array}{c}21 \\
279\end{array}$ & $\begin{array}{c}7 \\
93\end{array}$ \\
\hline Birth order & $\begin{array}{l}\text { First } \\
\text { Second \& third } \\
\text { Fourth/higher }\end{array}$ & $\begin{array}{l}76 \\
32 \\
30 \\
\end{array}$ & $\begin{array}{l}55 \\
23 \\
22\end{array}$ & $\begin{array}{c}126 \\
137 \\
37 \\
\end{array}$ & $\begin{array}{l}42 \\
46 \\
12\end{array}$ \\
\hline Gestational age & $\begin{array}{l}\text { Preterm } \\
\text { Term } \\
\text { Post term }\end{array}$ & $\begin{array}{c}91 \\
38 \\
9\end{array}$ & $\begin{array}{c}66 \\
28 \\
6\end{array}$ & $\begin{array}{c}10 \\
275 \\
15\end{array}$ & $\begin{array}{c}3 \\
92 \\
5\end{array}$ \\
\hline Duration of labor & $\begin{array}{l}12-19 \text { hours } \\
>20 \text { hours } \\
25-48 \text { hours } \\
5-30 \text { hours }\end{array}$ & $\begin{array}{c}8 \\
23 \\
104 \\
3\end{array}$ & $\begin{array}{c}6 \\
17 \\
75 \\
2\end{array}$ & $\begin{array}{c}250 \\
42 \\
8 \\
0\end{array}$ & $\begin{array}{l}83 \\
14 \\
3 \\
0\end{array}$ \\
\hline Apgar score at 1st minute & $\begin{array}{l}3 \& \text { below } \\
4 \text { to } 6 \\
7 \& \text { above }\end{array}$ & $\begin{array}{c}127 \\
7 \\
4\end{array}$ & $\begin{array}{c}92 \\
5 \\
3\end{array}$ & $\begin{array}{c}0 \\
44 \\
256\end{array}$ & $\begin{array}{l}15 \\
65 \\
85\end{array}$ \\
\hline Apgar score at $5^{\text {th }}$ minute & $\begin{array}{l}3 \& \text { below } \\
4 \text { to } 6 \\
7 \& \text { above }\end{array}$ & $\begin{array}{c}130 \\
7 \\
1 \\
\end{array}$ & $\begin{array}{c}94 \\
5 \\
1 \\
\end{array}$ & $\begin{array}{c}2 \\
26 \\
272 \\
\end{array}$ & $\begin{array}{c}1 \\
8 \\
91\end{array}$ \\
\hline Neonatal anemia & $\begin{array}{l}\text { Sever } \\
\text { Moderate } \\
\text { Mild }\end{array}$ & $\begin{array}{l}103 \\
22 \\
13\end{array}$ & $\begin{array}{c}75 \\
16 \\
9\end{array}$ & $\begin{array}{c}10 \\
68 \\
222\end{array}$ & $\begin{array}{c}3 \\
23 \\
74\end{array}$ \\
\hline New born sepsis & $\begin{array}{l}\text { Early onset } \\
\text { Late onset } \\
\text { No sepsis }\end{array}$ & $\begin{array}{l}74 \\
53 \\
11 \\
\end{array}$ & $\begin{array}{c}54 \\
38 \\
8 \\
\end{array}$ & $\begin{array}{c}4 \\
2 \\
294 \\
\end{array}$ & $\begin{array}{l}1.3 \\
0.6 \\
98\end{array}$ \\
\hline Birth asphyxia & $\begin{array}{l}\text { Sever asphyxia } \\
\text { Acute asphyxia } \\
\text { No asphyxia }\end{array}$ & $\begin{array}{l}104 \\
22 \\
12 \\
\end{array}$ & $\begin{array}{c}75 \\
16 \\
8 \\
\end{array}$ & $\begin{array}{c}0 \\
5 \\
295 \\
\end{array}$ & $\begin{array}{c}0 \\
2 \\
98 \\
\end{array}$ \\
\hline
\end{tabular}

Table 6. Coexisting medical characteristics of the mothers, Dilla University Referral Hospital, 2016-2018.

\begin{tabular}{|c|c|c|c|c|c|}
\hline \multirow[t]{2}{*}{ Variables } & & \multicolumn{2}{|c|}{ Cases (138) } & \multicolumn{2}{|c|}{ Control group (300) } \\
\hline & & No. & $\%$ & No. & $\%$ \\
\hline *History of chronic illness & $\begin{array}{l}\text { Yes } \\
\text { No }\end{array}$ & $\begin{array}{l}121 \\
17\end{array}$ & $\begin{array}{l}88 \\
12\end{array}$ & $\begin{array}{c}28 \\
272\end{array}$ & $\begin{array}{c}9 \\
91\end{array}$ \\
\hline History of hepatitis B-virus & $\begin{array}{l}\text { Positive } \\
\text { Negative }\end{array}$ & $\begin{array}{c}1 \\
137\end{array}$ & $\begin{array}{c}1 \\
99 \\
\end{array}$ & $\begin{array}{c}0 \\
300\end{array}$ & $\begin{array}{c}0 \\
100\end{array}$ \\
\hline VDRL status & $\begin{array}{l}\text { Reactive } \\
\text { Non-reactive }\end{array}$ & $\begin{array}{c}22 \\
116\end{array}$ & $\begin{array}{l}16 \\
84\end{array}$ & $\begin{array}{c}26 \\
274\end{array}$ & $\begin{array}{c}9 \\
91\end{array}$ \\
\hline HIV/AIDS & $\begin{array}{l}\text { Positive } \\
\text { Negative }\end{array}$ & $\begin{array}{c}11 \\
127 \\
\end{array}$ & $\begin{array}{c}8 \\
92 \\
\end{array}$ & $\begin{array}{c}13 \\
287\end{array}$ & $\begin{array}{c}4 \\
96 \\
\end{array}$ \\
\hline Malaria infection & $\begin{array}{l}\text { Yes } \\
\text { No }\end{array}$ & $\begin{array}{l}56 \\
90\end{array}$ & $\begin{array}{l}41 \\
65\end{array}$ & $\begin{array}{l}120 \\
180\end{array}$ & $\begin{array}{l}40 \\
60\end{array}$ \\
\hline Tuberculosis infection & $\begin{array}{l}\text { Yes } \\
\text { No }\end{array}$ & $\begin{array}{l}45 \\
93\end{array}$ & $\begin{array}{l}23 \\
67\end{array}$ & $\begin{array}{c}14 \\
286\end{array}$ & $\begin{array}{c}5 \\
95\end{array}$ \\
\hline Maternal anemia & $\begin{array}{l}\text { Severe } \\
\text { Moderate } \\
\text { Mild } \\
\text { No anemia }\end{array}$ & $\begin{array}{l}63 \\
33 \\
30 \\
12 \\
\end{array}$ & $\begin{array}{c}45 \\
24 \\
22 \\
9\end{array}$ & $\begin{array}{l}12 \\
23 \\
102 \\
163 \\
\end{array}$ & $\begin{array}{c}4 \\
8 \\
34 \\
54 \\
\end{array}$ \\
\hline
\end{tabular}

${ }^{*}$ Chronic illness (diabetes mellitus, renal disease, cardiac disease). 
Table 7. Factors associated with perinatal mortality (still births and early neonatal deaths), Dilla University Referral Hospital, Ethiopia, 2016-2018.

\begin{tabular}{|c|c|c|c|c|c|c|}
\hline Variables & & $\begin{array}{c}\text { Perinata } \\
\text { Still Births }(123, \%)\end{array}$ & $\begin{array}{l}\text { Deaths }(138) \\
\text { ENND }(15, \%)\end{array}$ & $\begin{array}{l}95 \% \text { CI for } \\
\text { (COR) }\end{array}$ & $\begin{array}{l}95 \% \text { CI for } \\
\text { (AOR) }\end{array}$ & P-value \\
\hline Birth interval in years & $\begin{array}{l}>2 \\
<2\end{array}$ & $\begin{array}{c}5(4.1) \\
118(95.9)\end{array}$ & $\begin{array}{c}5(33.3) \\
10(66.6)\end{array}$ & $\begin{array}{c}1 \\
0.23(0.13-0.21)\end{array}$ & $\begin{array}{c}1 \\
0.037(0.17-0.82)^{* *}\end{array}$ & 0.01 \\
\hline Chronic illness & $\begin{array}{l}\text { Yes } \\
\text { No }\end{array}$ & $\begin{array}{c}121(98.4) \\
2(1.6)\end{array}$ & $\begin{array}{l}9(60) \\
6(40)\end{array}$ & $\begin{array}{c}4.89(0.19-0.29) \\
1\end{array}$ & $\begin{array}{c}0.13(0.05-0.33)^{* *} \\
1\end{array}$ & 0.00 \\
\hline Birth weight in gram & $\begin{array}{l}1000-1499 \\
>2500-3999\end{array}$ & $\begin{array}{l}121(98.4) \\
2(1.6)\end{array}$ & $\begin{array}{l}12(80) \\
3(20)\end{array}$ & $\begin{array}{c}0.13(0.07-0.27) \\
1\end{array}$ & $\begin{array}{c}0.19(0.06-0.52)^{* *} \\
1\end{array}$ & 0.00 \\
\hline Use of parto-graph & $\begin{array}{l}\text { Yes } \\
\text { No }\end{array}$ & $\begin{array}{c}2(1.6) \\
121(98.4)\end{array}$ & $\begin{array}{c}1(6.7) \\
14(93.3)\end{array}$ & $\begin{array}{c}1 \\
0.08(.04-.17)\end{array}$ & $\begin{array}{c}1 \\
0.10(0.03-0.26)^{* *}\end{array}$ & 0.00 \\
\hline Obstetric com-plications & $\begin{array}{l}\text { APH } \\
\text { Mal-presentation } \\
\text { PIH } \\
\text { Mal-presentation }\end{array}$ & $\begin{array}{l}55(45) \\
2(2) \\
53(43) \\
2(2)\end{array}$ & $\begin{array}{l}6(40) \\
0(53) \\
8(53) \\
0(20)\end{array}$ & $\begin{array}{c}0.07(0.02-1.23)^{*} \\
1 \\
0.09(0.01-1.33)^{*} \\
1\end{array}$ & $\begin{array}{c}0.03(0.01-0.023)^{* *} \\
1 \\
0.02(0.01-0.033)^{* *} \\
1\end{array}$ & $\begin{array}{l}0.02 \\
0.00\end{array}$ \\
\hline
\end{tabular}

1: Indicates the reference categories*: Indicates significant association (P-value $<0.25{ }^{* *}$ : Indicate highly significant association $(\mathrm{P}$-value $<0.05)$.

\section{Discussion}

In this analysis of the hospital dataset, we found that perinatal deaths were adversely associated with a number of obstetric outcomes during perinatal period. We observed that the PMR was nearly three-fold of the national PMR estimated for 2016, Ethiopia Demographic and Health Survey (EDHS). ${ }^{10}$ The possible explanations of the differences in the PMR were the variation in the scope of the studies and the level that the results were inferred for. However, the finding was almost comparable with the hospital-based studies conducted in different parts of Ethiopia. The main reason for increased rate of perinatal mortality in both studies is probably because most of the mothers of the cases came very late and with serious obstetric complications and mechanical causes, mainly obstructed labor with or without uterine rupture. Therefore, perinatal mortality is highly prone for overestimation in hospital based studies. ${ }^{11-14}$ But, the PMR in this study was found to be high as compared to population-based studies conducted in north and northwest Ethiopia. ${ }^{15,16}$

We observed that birth interval of $<2$ years, low birth weight, nonuse of partograph and history of chronic illness found to had significant association with both still births and ENND. The findings were comparable with the findings from EDHS, 2016 where the causes of stillbirths and early neonatal deaths were closely linked. ${ }^{9}$ However, predictive models analysis of population based prospective cohort study in low and middle income countries disagreed with the current findings: gestational age at enrollment, maternal age, birth order, parity hypertension, and severe pre-eclampsia, or eclampsia found to be important predictors of intra partum stillbirth in the prenatal and pre-delivery. ${ }^{17}$

Our result suggested that birth interval $<2$ years had 0.037 times greater risk of perinatal deaths in comparison to birth interval of more than two years. This is in line with the finding of the longitudinal study conducted in northwest Ethiopia. ${ }^{16}$ Too many closely spaced pregnancies is a phenomena related to sibling competitions recognized as the maternal depletion syndrome, ${ }^{18}$ and associated with premature rupture of membranes and puerperal endometritis which can cause perinatal deaths. ${ }^{19}$ Low birth weight was found to be 0.19 times at higher risk of neonatal death [AOR 0.19; 95\% CI (0.02-0.052)] in comparison to normal birth weight. This is consistent with retrospective study conducted in India, ${ }^{20}$ and predictive models analysis of population based prospective cohort study in low and middle income countries where birth weight was the most important variable for predicting the risk of neonatal mortality that provided the strongest evidence that the risk of mortality increased with decreasing in birth weight in both the delivery/day 1 and post-delivery/day 2 scenarios.

$\mathrm{APH}$ in the predictive models analysis of population based prospective cohort study in low and middle income countries was the most important predictor of neonatal deaths. The finding is consistent with the current study in which APH had 0.03 times high risk of perinatal deaths [AOR 0.03; 95\% CI (0.01-0.023)] ${ }^{17}$ However, the finding of the current study was inconsistent with the findings of the study conducted in Addis Ababa public hospitals. ${ }^{10,11}$ The study demonstrated follow up of labor with pan- tographs had protective effect of $10 \%$ [AOR 0.10 ; 95\% CI (0.01-0.02)] against perinatal death than not followed up with pantographs. The finding is consistent with perinatal death audit carried out in semiurban hospital in Kampala, Uganda where updates on use of pantographs reduced a deaths rate by 5 per 1,000 total births after introduction of the audits compared to the death rate before the audit. ${ }^{21}$

The cases of perinatal deaths who were suffered from PIH and having a history of chronic illness had 0.02/ 0.13 times higher risk of perinatal deaths [AOR 0.02; 95\% CI (0.01-0.033)] and [AOR 0.13; 95\% CI (0.05-0.33) than their counter parts respectively. The findings were consistent with the study conducted in Odisha, India, which demonstrated ranges of fetal pregnancy outcomes: fetal deaths that were occurred as a result of fetal complications including a low birth weight, preterm birth and intra uterine growth retardation resulted in acidosis and less oxygen supply to fetus. In addition, some pre-eclamptic cases lead to severe preeclampsia associated with various maternal complications including the risk of stroke; kidney and liver dysfunction. ${ }^{22}$

\section{Conclusions}

Low birth weight, birth interval $<2$ years, previous history of chronic illness, $\mathrm{APH}$ and PIH were identified as increasing the risk of perinatal deaths. However, following labor with partograph was identified as decreasing the risk of perinatal deaths. Birth interval of $<2$ years resulted from nonuse of modern contraceptive and poor quality of intra partum care reflected by nonuse of partograph for labor follow up 
are the important determinant factors for perinatal loss. The study suggests that the risk of perinatal deaths could be improved by early investigation of pregnant mothers during ANC follow up. Appropriate monitoring of labor using partograph, immediate newborn care and interventions to prolong birth interval could be resulted in significant reductions of perinatal mortality. Lots of ENND caused as a result of low birth weight and could be averted by optimizing immediate newborn care and neonatal resuscitation.

\section{Limitations of the study}

The hospital record based data was utilized in addition to the participants driven information to overcome the possibilities of recall biases. Intra partum and antepartum stillbirth differentiation can be associated with identification errors, but training of the data collectors, several quality checks and subgroup analyses were made to minimize this error. There is a possibility of potential confounders like individual health status and a wide range of sociocultural norms that were not captured. Nonetheless, as the study results are based on a sufficient number of participants over 3 years, the potential impact of confounders on the study result should be low. Although generalizability of the results could be questioned due to the limited scopes of the data, the results are likely to be pertinent to many of the hospitals similar to those of the study settings.

\section{References}

1. Allanson E, Tunçalp Ö, Gardosi J, et al. Classify the causes of perinatal death. World Health Organization 2016;94:79. available

https://www.researchgate net/publication/292676625.

2. Bradley SEK, Winfrey W, Croft TN. Contraceptive Use and Perinatal Mortality in the DHS: An Assessment of the Quality and Consistency of Calendars and Histories. DHS Program, 2015. Available from: www.dhsprogram.com/publications/publicationMR17-Methodological-Reports.cfm.

3. WHO, USAID, Panamerican Health Organization, et al. Latin American Center for Perinatology Women and Reproductive Health. Plan of action to accelerate the reduction of maternal mortality and severe maternal morbidity: monitoring and evaluation strategy. Montevideo: CLAP/WR; 2012.
(CLAP/WR. Scientific Publication; 1593-02). http://perinatal.bvsalud.org/.

4. UNICEF. Levels and trends in child mortality. UN Inter-agency Group for Child Mortality Estimation. Published 2018. Accessed September 1, 2020. Available from: https://data.unicef.org/wpcontent/uploads/2018/10/ChildMortality-Report-2018.pdf.

5. Liu L, Oza S, Hogan D, et al. Global, regional and national causes of child mortality in 2000-13, with projections to inform post-2015 priorities: an updated systematic analysis. Lancet 2015;385:430-40

6. Richardus JH, Graafmans WC, Verloove SP, et al. The perinatal mortality rate as an indicator of quality of care in international comparison. Medical Care 1998;36:54-66.

7. World Health Organization. The Global Strategy for Women's, Children's and Adolescents' Health (2016-2030): Sustanable Development Goal Report, Every Woman Every Child 2015. https://www.everywomaneverychild.or g/global-strategy.

8. Little GA, Keenan WJ, Niermeyer S, et al. Neonatal nursing and helping babies breathe: an effective intervention to decrease global neonatal mortality. Newborn and Infant Nursing Reviews 2011;11:82-8.

9. Central Statistical Agency (CSA). Ethiopia mini demographic and health survey 2014. Addis Ababa: Central Statistical Agency [Ethiopia]. Available $\begin{array}{lllll}\mathrm{f} & \mathrm{r} & \mathrm{O} & \mathrm{m} & \text { : }\end{array}$ http://www.healthdata.org/ethiopia

10. Central Statistical Agency (CSA) Ethiopia and ICF. The 2016 Ethiopia demographic and health survey key findings. CSA and ICF, Addis Ababa, Ethiopia, and Rockville, Maryland, USA, 2017. Available from: https://dhsprogram.com/pubs/pdf/SR24 1/SR241.pdf.

11. Bayou G, Berhan Y. Perinatal mortality and associated factors: A case control study. Ethiop J Health Sci 2012;22:15362.

12. Getiye Y, Fantahun M. Factors associated with perinatal mortality among public health deliveries in Addis Ababa, Ethiopia, an unmatched case control study. BMC Pregnancy Childbirth 2017; 17:245.

13. Sullivan KM, Soe MM. Sample size for cross-sectional \& cohort studies \& clinical trials. OpenEpi, 2007. Available f $\quad r \quad$ o $\quad$ m :

http://www.openepi.com/PDFDocs/SS

CohortDoc.pdf.

14. Asefa D, Muleta G, Araya F, et al. Pattern of perinatal mortality among deliveries at Jimma University Teaching Hospital, South-West Ethiopia. J Woman Health Issues 2016:5:1000252.

15. Yirgu R, Molla M, Sibley L, Gebremariam A. Perinatal Mortality Magnitude, Determinants and Causes in West Gojam: Population-Based Nested Case-Control Study. PLoS ONE 2016;11:e0159390.

16. Andargie G, Berhane Y, Worku A, et al. Predictors of perinatal mortality in rural population of Northwest Ethiopia: a prospective longitudinal study. BMC Public Health 2013;13:168.

17. Shukla VV, Eggleston B, Ambalavanan $\mathrm{N}$, et al. Predictive modeling for perinatal mortality in resource limited settings: Original investigation. JAMA Netw Open 2020;3:e2026750.

18. David McKinney, Melissa House, Aimin Chen,etal. The influence of interpregnancy interval on infant mortality.Am J Obstet Gynecol 2017;216:316.e1-316.e9.

19. Simetka O, Michalec I, Crkvenjas ZN, et al. Toxic epidermal necrolysis complicating antibi-otic treatment of puerperal endometritis: A case report. Ginekol Pol 2015;86:315-7.

20. Shilpi Srivastava, Sanjaya Sharma, Sushila Kharkwal, etal. A study of causes of perinatal mortality in tertiary center in Bundelkhand region. Int J Reprod Contracept Obstet Gynecol 2015;4:4346.

21. Nakibuuka VK, Okong P, Waiswa P, et al. Perinatal death audits in a peri-urban hospital in Kampala, Uganda. Afr Health Sci 2012;12:435-42.

22. Jena M, Mishra S, Jena $S$, et al. Pregnancy induced hypertension \& pre eclampsia: Pathophysiology \& recent management trends: A review. J Pharmaceut Res Allied Sci 2016;5:32634. 